\title{
ANÁLISE DO TEMA VIROLOGIA EM LIVROS DIDÁTICOS DE BIOLOGIA DO ENSINO MÉDIO
}

\author{
Marcus Vinicius de Aragão Batista* \\ Marlécio Maknamara da Silva Cunha** \\ Alexandre Luna Cândido***
}

RESUMO: A Virologia proporciona conhecimentos básicos e aplicados para serem utilizados no dia-a-dia das pessoas visando melhorar sua qualidade de vida no tocante à saúde coletiva. Entretanto, há uma carência muito grande de estudos que analisam esses conceitos nos livros didáticos do ensino médio. Esta pesquisa analisou os principais conceitos da Virologia nos livros didáticos de Biologia do ensino médio mais utilizados em escolas do município de Aracaju, Sergipe. A análise foi feita com ênfase na verificação de erros conceituais e em uma possível consideração do conhecimento prévio dos alunos. Os livros apresentaram problemas com relação aos conceitos empregados e à contextualização. Os resultados obtidos indicam a necessidade de reformulação e atualização desses recursos didáticos para o auxílio no ensino da Virologia.

Palavras-chave: Livro Didático. Virologia. Ensino Médio.

\section{ANALYSIS OF VIROLOGY IN HIGH SCHOOL BIOLOGY TEXTBOOKS}

ABSTRACT: The study of viruses provides basic and applied knowledge to be used in people's daily actions aimed at the improvement of the quality of life concerning collective health. However, there is a considerable lack of studies that analyze those concepts in the high school textbooks. This research analyzed the main concepts of the Virology in high school Biology textbooks widely used at schools of Aracaju, Sergipe state. The analysis was made with emphasis on the verification of conceptual mistakes whereas taking into consideration the students' previous knowledge. The books presented problems regarding the applied concepts and contextualization. The obtained results indicate a need for the reformulation and updating of those didactic resources with a view to assist in the teaching of Virology.

Keywords: Textbooks. Virology. High School Teaching. 


\section{INTRODUÇÃO}

Os livros didáticos representam um papel muito importante para a educação, sendo bastante valorizados como material de apoio por órgãos internacionais que financiam recursos para a educação (TORRES GARCÍA et al., 2002). No ensino de Ciências a importância dos livros didáticos é ainda maior, uma vez que representam, em muitos casos, o único material de apoio disponível para professores e alunos.

Os livros didáticos de Ciências devem ser capazes de promover a reflexão sobre vários aspectos da realidade e ainda estimular o sentimento de investigação do aluno (VASCONCELOS; SOUTO, 2003). Para isso, os professores têm papel bastante relevante, devendo ser capazes de utilizar esse recurso para suscitar nos alunos experiências pedagógicas significativas, diversificadas e alinhadas com a sociedade em que estão inseridos, que são exigências do contexto educacional contemporâneo.

Tendo em vista a importância dos livros didáticos, o Ministério da Educação (MEC), em 1995, estabeleceu como prioridade o aprimoramento dos referidos artefatos. Entretanto, ainda existem livros que contrariam tal determinação, contendo erros conceituais ou informações equivocadas, apontando para a necessidade da avaliação qualitativa do livro didático (BRASIL, 2002). Desde então, várias ações têm sido realizadas pelo governo brasileiro com o objetivo de melhorar a qualidade dos livros didáticos.

Do ponto de vista jurídico, o decreto 91 54/85 implantou o Plano Nacional sobre o Livro Didático (PNLD), que é o mecanismo que regulamenta legalmente a questão do livro didático. Recentemente a Resolução/CD/FNDE $\mathrm{n}^{\circ}$ 603, de 21 de fevereiro de 2001, passou a ser o mecanismo que organiza e regula o PNLD (NÚÑEZ et al., 2003). Em 1997, foi criado, pela Secretaria de Educação Básica do MEC, o Guia do PNLD que apresentava não só os princípios e critérios que nortearam a avaliação, como também as resenhas das obras recomendadas para escolha do professor (BRASIL, 2006a).

No ano de 2003 o MEC implantou, com a Resolução n 38 do Fundo Nacional para o Desenvolvimento da Educação (FNDE), o Programa Nacional do Livro Didático para o Ensino Médio (PNLEM), que prevê a distribuição de livros didáticos para os alunos do ensino médio público de todo o país. A partir de 2006, começaram a ser distribuídos os livros didáticos de Biologia para todos os alunos do ensino médio do país, exceto para Minas Gerais por possuir programa próprio (BRASIL, 2006b).

Os Parâmetros Curriculares Nacionais para o Ensino Médio (PCNEM) foram elaborados com o intuito de promover os princípios da reforma curricular e orientar os professores na busca de novas abordagens e metodologias, orientando os professores na questão da contextualização e interdisciplinaridade, incentivando o raciocínio e a capacidade de aprender (BRASIL, 1999). Para a Biologia, o PCNEM considera que é importante dar ênfase ao 
conhecimento cognitivo dos estudantes, relacionando suas experiências, e os diferentes significados e valores que essa ciência pode ter para eles, para que a aprendizagem seja significativa (BRASIL, 1999).

Há uma falta de critérios para a escolha do melhor recurso de auxílio às aulas ministradas pelos professores, e isso causa muitos problemas na utilização dos livros no sistema educacional, uma vez que, na maioria dos casos, o professor usa apenas uma única fonte de consulta, limitando o conjunto de habilidades que o aluno tem que desenvolver ao longo desse processo (ABUD, 1994).

A seleção dos livros didáticos a serem utilizados é de grande importância para o aprendizado dos alunos e deve ser feita baseada no contexto real de vida dos estudantes, percebidos pelos seus respectivos professores, que devem trabalhar como construtores ativos do saber na escolha dos livros (RAMALHO et al., 2000). Essa escolha deve estar vinculada à concepção de educação do professor, aos objetivos da proposta político-pedagógica da unidade escolar e ao processo de elaboração do currículo da escola, focando sempre nos alunos (LIBÂNEO, 1994).

Para que os professores realizem uma boa seleção dos livros didáticos, é necessário que haja mecanismos bem estabelecidos para a avaliação das obras didáticas, que devem se basear na premissa de que seus textos devem auxiliar aos professores na busca por caminhos possíveis para sua prática pedagógica. Esses caminhos não são únicos, posto que as referências não devam se restringir ao espaço das salas de aula e das obras didáticas, entretanto são importantes orientações para que os professores busquem, de forma autônoma, outras fontes e experiências para complementar seu trabalho em sala de aula (BRASIL, 2006b). Assim, é de extrema importância a realização de pesquisas na área de Ensino de Ciências que visem avaliar a qualidade dos conteúdos abordados nos livros didáticos.

Um dos conteúdos mais importantes das Ciências Biológicas é a Microbiologia, que além de apresentar outras importâncias, está muito associado à Saúde Pública, e o PCNEM mostra que é fundamental que o ensino de Biologia desenvolva temas associados com patógenos microbiológicos, preparando-os para a realização de ações de intervenção que visem à transformação dessas condições (BRASIL, 1999).

Dentro desta perspectiva, os conceitos acerca da Virologia, que é uma disciplina de grande interesse para o desenvolvimento de pesquisas na área de Ciências Biológicas e da Saúde, devem ser bastante explorados pelos professores e livros didáticos para formar agentes transformadores de uma realidade. Por exemplo, no cotidiano das pessoas, o simples fato de lavar as mãos ou não cuspir no chão já são medidas de controle de contaminação viral. Assim, o estudo dos vírus proporciona conhecimentos básicos que as pessoas devem utilizar no diaa-dia para aumentar a qualidade de vida nas cidades, por meio da melhoria da saúde da população.

Entretanto, há uma carência muito grande de estudos que analisam esses conceitos nos livros didáticos do ensino médio, podendo estar desatu- 
alizados ou não-contextualizados com a realidade dos alunos, tornando-se um problema para o ensino e aprendizagem dessa disciplina.

Em vista da importância em se aprender Virologia no ensino médio, o presente trabalho torna-se importante por avaliar os conceitos dessa disciplina nos livros didáticos mais utilizados na cidade de Aracaju, estado de Sergipe. Esse material didático é um importante acessório para o auxílio no processo de ensino e aprendizagem que os professores e alunos irão ter, ainda que a literatura especializada na área ressalte que ele não deve ser o único elemento central desse processo.

\section{PROCEDIMENTOS METODOLÓGICOS}

\subsection{Seleção dos Livros Didáticos}

A seleção dos livros didáticos de Biologia do Segundo ano do Ensino Médio, que é a série em que geralmente se aborda esse assunto, foi feita por meio de uma pesquisa realizada nas principais editoras da cidade de Aracaju, estado de Sergipe. As editoras consultadas foram a Ática, Saraiva, Moderna e Scipione. Essa consulta foi realizada por meio de uma visita e uma entrevista informal com funcionários das mesmas. Um livro que é voltado para o Primeiro ano do Ensino Médio também foi selecionado por possuir o conteúdo de Virologia (Tabela 1).

Tabela 1: Lista de livros analisados

\begin{tabular}{|c|c|c|c|}
\hline Obra & Autor & Editora & Ano de Edição \\
\hline 1) Biologia Hoje vol. 1 & LINHARES, S.; GEWANDSZNAJDER, F. & Ática & 2000 \\
\hline 2) Biologia Atual vol. 2 & PAULINO, W. R. & Ática & 1998 \\
\hline 3) Biologia Hoje vol. 2 & LINHARES, S.; GEWANDSZNAJDER, F. & Ática & 1998 \\
\hline 4) Bio vol. 2 & LOPES, S. & Saraiva & 2002 \\
\hline 5) Biologia dos organismos vol. 2 & AMABIS, J. M.; MARTHO, G. R. & Moderna & 1999 \\
\hline 6) Biologia vol. único & SOARES, J. L. & Scipione & 1997 \\
\hline
\end{tabular}

Estes autores e obras serão referidos neste trabalho por referência numérica de 1 a 6 de acordo com a tabela anterior.

\subsection{Análise dos livros didáticos}

A análise foi realizada com ênfase no tema Virologia com o auxílio de uma ficha de avaliação para a coleta de dados (Tabela 2). Os conteúdos básicos da Virologia nesses livros foram analisados de acordo com critérios qualitativos e quantitativos considerados relevantes e referentes à apresentação do tema.

Os critérios utilizados foram organizados de uma maneira que fosse possível subdividir os livros didáticos e, assim, facilitar a análise. Os textos dos livros foram avaliados quanto à presença de erros conceituais, verificando se o conteúdo científico estava adequado; se a escrita contextualizava com o cotidiano dos alunos, proporcionando uma aprendizagem significativa; se existia 
uma abordagem das principais doenças causadas por vírus, principalmente as epidemiologicamente relevantes para a região Nordeste; se havia propostas de sugestão de leitura em outras fontes bibliográficas - textos complementares são importantes para uma abordagem mais prática do conteúdo; se os exemplos utilizados eram apresentados de forma clara, objetiva e interligada ao assunto, levando os alunos a perceberem e entenderem a importância dos vírus no seu cotidiano; se existia espaço para discussões e debates que criam senso crítico nos alunos; e, por fim, se era abordada uma relação do conteúdo com a Biotecnologia e a Nova Biologia, assuntos em bastante evidência na mídia atualmente.

Tabela 2 - Ficha de avaliação dos livros didáticos de Biologia acerca do assunto Virologia.

\section{CRITÉRIOS OBSERVADOS}

Avaliação

2 - Número de páginas dedicadas ao assunto

3 - Figuras:

" com legendas adequadas

\section{" quantidade}

" claras, explicativas e coerentes com o texto

" tipos de ilustrações (fotos/desenhos)

4 - Existem referências atualizadas em relação ao ano de publicação

5 - Existem erros conceituais/conceitos fragmentados

6 - Presença de exemplificações claras, relacionando-se com o dia-a-dia do aluno

7 - Utiliza vocabulário atualizado, adequado e correto

8 - Estimulam o raciocínio crítico e motiva 0 aluno

9 - Sugestões de leitura complementar

10 - Propõem atividades em grupo e discussões em relação ao assunto

11 - Estabelecem relações entre os capítulos estudados anteriormente

12 - Levam em conta o conhecimento prévio do aluno

13 - Isenção de erros ortográficos

14 - A linguagem é clara

15. Tratam de aspectos ligados à Biotecnologia

16 - Apresentam exercícios que possibilitam a aprendizagem significativa

17 - Aborda corretamente os assuntos:

" estrutura viral

" ciclos de replicação

" bacteriófagos

" vírus de plantas

" vírus de animais

" retrovírus

" saúde humana (doenças virais)

" vírus de importância regional (nordeste)

Os dados coletados foram então analisados e agrupados em planilhas, assim como na forma de gráficos para uma melhor visualização dos resultados. Foram utilizados gráficos que mostrassem, de forma clara, a distribuição e as tendências dos dados, facilitando o entendimento da análise. 


\section{RESULTADOS E DISCUSSÃO}

No total, foram analisados seis livros didáticos, que foram indicados como os mais vendidos das quatro editoras pesquisadas. A escolha desses livros foi feita partindo da premissa de que os livros mais vendidos nas editoras da cidade são os livros mais utilizados pelos alunos e professores, sendo esses os mais importantes para a presente pesquisa.

A importância que é dada a determinado assunto em um livro didático pode ser medida, por exemplo, pelo número de páginas que o autor dedica a ele (CARLINI-COTRIM; ROSEMBERG, 1991). Assim, alguns autores deram mais importância ao estudo dos vírus do que outros, escrevendo mais páginas sobre esse tema (Figura 1).

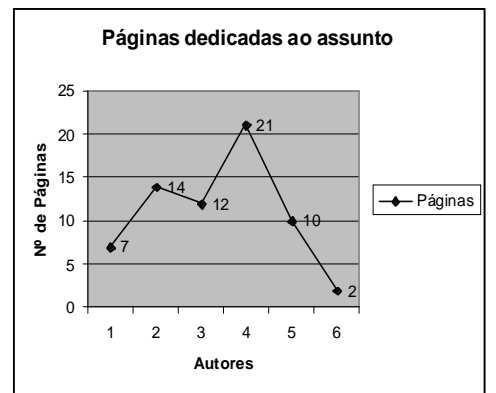

Figura 1 - Número de páginas dedicadas ao tema Virologia.

Em contrapartida, a importância das imagens nos livros didáticos está no fornecimento de subsídios para uma melhor compreensão e avaliação da natureza das demandas desse texto (MARTINS; GOUV A, 2005). Seguindo esse raciocínio, os autores apresentaram uma boa quantidade de figuras nos seus livros em relação à quantidade de páginas que abordam o assunto (respectivamente: 06, 09, 10, 18, 15 e 06 figuras). Entretanto, a maioria cometeu algum erro nas legendas (Figura 2). Os autores 1, 3, 5 e 6 não informaram, nas figuras referentes aos ciclos de replicação, o tipo de ciclo que estava sendo ilustrado, lítico ou lisogênico. $\mathrm{Na}$ obra 2, uma figura apresenta, na legenda, projeções da Universidade de Harvard mas não há nada na ilustração sobre essas projeções. O único livro em que as legendas estavam todas corretas e completas foi o 4.

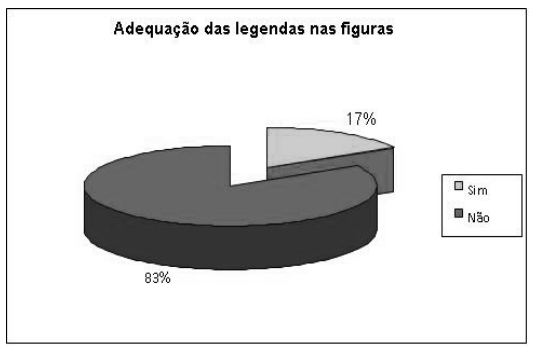

Figura 2 - Livros com legendas adequadas ou não. 
As obras 2 e 6 apresentaram figuras que não estão muito bem correlatas no texto, o que pode atrapalhar a compreensão dos estudantes. O restante dos autores apresentou figuras claras, explicativas e coerentes com o texto. É importante também mesclar fotos e desenhos para que facilite aos leitores o entendimento do assunto e a relação com a realidade. Em vista disso, todos os autores demonstraram tanto desenhos esquemáticos quanto fotos.

A velocidade das mudanças científicas transforma incessantemente o conhecimento (COLLETTO, 2005). Assim, é necessário que os livros didáticos também acompanhem essas mudanças e atualizem seus textos, utilizando referências atualizadas em relação ao ano de publicação do livro. De forma a apoiar a formação continuada dos professores, na maioria das vezes impossibilitados pela demanda de trabalho, de atualizar-se em sua área específica é um dos motivos pelo qual o livro didático deve trazer informações atualizadas. Dessa forma, a escolha do livro deve ser criteriosa e afinada com as características da escola, alunos e contexto educacional em que estão inseridos (BRASIL, 2006). Todos os autores apresentaram referências com datas próximas à da publicação de seus respectivos livros, entretanto o autor 5 indicou a leitura de um texto muito antigo, datando de 1987, no final do capítulo.

As obras 1 e 3 , que pertencem ao mesmo autor, apresentaram erros conceituais ou conceitos fragmentados. $\mathrm{O}$ autor 1 definiu bacteriófagos como vírus que infectam Escherichia coli, mas os fagos podem infectar outras bactérias também, não só a E. coli. Já a obra 3 define parasitas como causadores de prejuízos ao hospedeiro, o que não é necessariamente verdade. Existem parasitos que não conferem nenhum prejuízo ao hospedeiro, sendo importante esclarecer isso aos alunos. As demais obras não possuem erros conceituais contundentes (Figura 3).

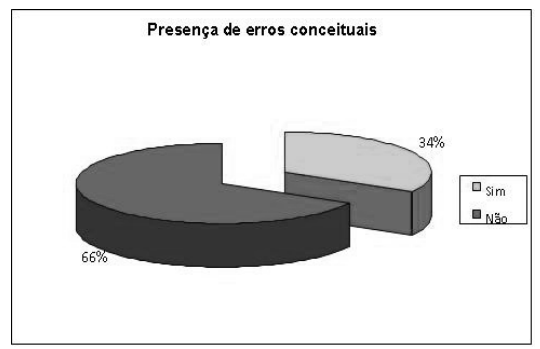

Figura 3 - Presença ou ausência de erros conceituais nos livros analisados.

Outros critérios de análise também foram considerados, como a utilização de vocabulário atualizado, adequado e correto; a isenção de erros ortográficos; e possuir linguagem clara, que também são aspectos necessários para um recurso didático eficiente. Todas as obras aqui analisadas possuem esses requisitos, não interferindo assim no aprendizado do aluno.

As leituras complementares devem transpor o texto tradicional de livro didático, apresentando aos leitores outra abordagem do tema, mais atual e 
mais ampla, relacionando com a realidade dos alunos. O objetivo é atrair a curiosidade do estudante contextualizando o conteúdo. Assim, os autores 1, 2, 3, 4 e 5 incluíram em seus livros sugestões de leituras complementares (Figura 4). Apenas o autor 6 não abordou esse tipo de leitura, provavelmente por ser um livro volume único onde a prioridade é tornar o texto bastante compacto e resumido.

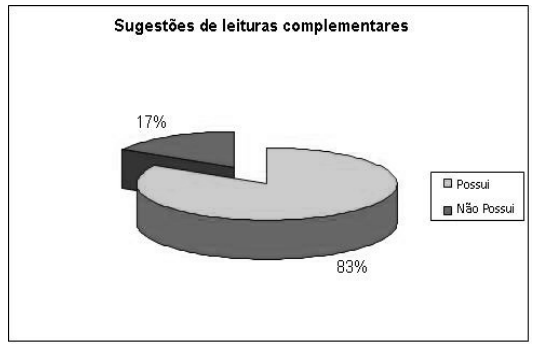

Figura 4 - Livros que incluíram sugestões de leituras complementares.

A Biotecnologia é um processo tecnológico que permite a utilização de material biológico para fins industriais. O estudo dos vírus está muito relacionado com essa tecnologia e por isso é necessário que os livros didáticos façam essa relação para que os estudantes entendam mais essa importância da Virologia e se sintam mais motivados a conhecer o conteúdo. Quanto a este ponto, nenhum dos autores tratou, em seus livros, de aspectos ligados à biotecnologia no capítulo que diz respeito ao estudo dos vírus, não fazendo a relação adequada entre eles.

A obra 1, em relação à estrutura viral, não a descreve de forma completa, simplesmente comenta a existência de um capsídeo que contém o ácido nucléico dentro e ilustra com algumas figuras. $\mathrm{Na}$ verdade alguns vírus também podem possuir um envelope lipídico que envolve o capsídeo com glicoproteínas externas, espículas, e, como os bacteriófagos, possuir fibras para a fixação. Faltou o autor comentar também a existência do termo vírion, que indica a forma intracelular do vírus. $\mathrm{O}$ fato de mostrar algumas dessas estruturas apenas nas figuras pode passar uma impressão errônea aos estudantes de que elas não são importantes e, que estão ali apenas para despertar a curiosidade. Esse autor ainda afirma que os vírus possuem tamanhos entre 0,03 e 0,3 $\mu \mathrm{m}$, e segundo Rácz e Menck (2004), existem vírus menores que 0,03 $\mu \mathrm{m}$, medindo $0,018 \mu \mathrm{m}$.

No que diz respeito aos ciclos de replicação dos vírus, a obra 1 descreve os dois ciclos (lítico e lisogênico) corretamente. Em relação aos bacteriófagos, como comentado anteriormente, esse autor comenta que "atacam um tipo de bactéria chamada E. colı', que está equivocado.

Nesta obra não há menção aos vírus vegetais, nem de animais (de interesse veterinário), nem aos retrovírus. Quanto aos vírus de interesse médico, apenas são citadas algumas doenças, sem mencionar que tipo de vírus causa cada 
uma. Não há também relação com os vírus que causam doenças frequentes aqui no nordeste brasileiro. Segundo os PCNs, relacionar os problemas de saúde com a realidade dos alunos é importante para o desenvolvimento de um conhecimento mais amplo e sedimentado, sendo necessária a contextualização dos conteúdos. Isso não ocorreu porque, apesar dos livros estarem sendo utilizados pelos alunos na cidade de Aracaju, os autores desta obra são da região Sudeste do país, não relacionando a problemática da região Nordeste.

A obra 2, à respeito da estrutura viral, apenas escreve que os vírus são "constituídos basicamente por uma cápsula de natureza protéica em cujo interior existe apenas um tipo de ácido nucléico”. Na verdade ele foi bem mais simplista do que a primeira obra, não definindo nem a cápsula como capsídeo. Outras estruturas, como já comentado anteriormente, também foram omitidas. Nesta obra há também o esquema de um bacteriófago divido em cabeça e cauda, sem entretanto comentar a presença do capsídeo, dos capsômeros, das fibras da cauda e da bainha. Segundo Rácz e Menck (2004), basicamente os vírus consistem em ácido nucleico envolvido por uma capa proteica, entretanto é necessário citar que pode haver outras estruturas que são importantes para o entendimento de outros conteúdos.

Em relação aos ciclos de replicação, essa obra apenas explica o ciclo replicativo de um fago sem mostrar que se trata de um ciclo lítico. Também não comenta a existência do ciclo lisogênico, o que é importante para o entendimento das infecções latentes de algumas doenças. Para o ensino médio, os alunos precisam saber da existência desse ciclo, apesar de não precisarem entender os mecanismos da infecção.

Esta obra, assim como a primeira, não menciona vírus vegetais e nem os de importância veterinária. Entretanto, ele cita um Baculovírus que ataca a lagarta-de-soja, sendo usado como controle biológico importante para a agricultura. É interessante que o autor tenha citado esse vírus porque mostra uma das importâncias da Virologia.

A definição dos retrovírus já é abordada nessa obra como os vírus de RNA que produzem moléculas de DNA, na presença da enzima transcriptase reversa. Esta obra também apresenta um esquema (RNA ? DNA ? RNA ? Proteínas), o que facilita o entendimento dos alunos por meio do processo de transposição didática, que segundo Chevallard (1999) transforma o conhecimento científico de tal forma que ele se transforme em um conhecimento ensinável para os alunos. Este é outro avanço em relação à obra 1, que nem menciona a existência dos retrovírus, importantes para entender o vírus HIV causador da Síndrome da Imunodeficiência Adquirida Humana (AIDS ou SIDA).

Ao contrário da obra 1, ele explicitou as principais viroses humanas, explicando que cada vírus tem preferência por um determinado tipo celular. As principais doenças causadas por vírus, nesta obra foram colocadas em uma tabela com nome da doença, meio de transmissão, como causa a infecção, como 
se faz o controle e quais são os sintomas característicos. Para a gripe, por exemplo, o autor afirma que não há nenhum controle, o que está errado, pois existe controle feito por meio da vacinação de idosos e há o combate aos sintomas. Pode não ser um controle total, mas é preciso esclarecer isso aos alunos. É importante que as obras citem medidas de controle de viroses respiratórias uma vez que medidas simples de higienização ajudam bastante nesse controle.

Em relação à AIDS e à dengue, o autor dá mais detalhes como a história da doença, patogenia, sintomas, transmissão, prevenção e tratamento. Apesar de essas doenças serem importantes para a região Nordeste pelo número de casos que nela ocorre, o autor não comenta isso. Outro aspecto importante é um texto falando do Ebola, um vírus exótico bastante letal que vitimou muitas pessoas na África recentemente, e um texto explicando o motivo de não se tratar as viroses com antibióticos. É muito importante que os estudantes tenham isso em mente para não utilizarem antibióticos desnecessariamente, evitando a automedicação e, assim, um aumento de bactérias resistentes a antimicrobianos, em um país onde $50 \%$ das vendas de medicamentos tradicionais correspondem à automedicação (JÁCOME, 2001).

A maneira como a obra 3 define a estrutura viral é direta e completa, definindo todas as estruturas que podem ser encontradas nos vírus, diferentemente das obras 1 e 2, embora seja o mesmo autor da obra 1. Entretanto, comete o mesmo erro do volume 1 de sua coleção no que diz respeito ao tamanho dos vírus. Essa obra também define vírion erroneamente quando diz que é a forma extracelular do vírus, sendo na verdade a forma intracelular. Assim como a obra $2 \mathrm{fez}$, este também destacou que os vírus "atacam apenas um determinado tipo de célula", sendo importante para entender porque os vírus causam doenças em alguns sistemas do corpo e outros não. Outro ponto positivo dessa obra é que o autor mostra a importância da cápsula e das glicoproteínas que nela estão inseridas, na ligação com receptores específicos das células alvo, o que os outros dois livros não fizeram.

Essa obra também demonstrou os dois ciclos de replicação viral corretamente, utilizando um bacteriófago como modelo, assim como ele fez na obra 1 aqui analisada. Além disso, ele também comentou a reprodução dos vírus de RNA e o dos retrovírus, o que as obras 1 e 2 não fizeram. Os fagos são retratados aqui como "vírus que atacam bactérias, reproduzindo-se em seu interior", o que está correto, diferentemente do que ele mesmo escreveu na obra 1 definindo bacteriófagos como vírus que atacam apenas E. coli. Entretanto, é importante ressaltar que as obras deveriam utilizar termos mais corretos como "vírus infectam bactérias", introduzindo assim uma definição para o termo infecção.

No referido livro também não há menção aos vírus vegetais e nem aos de importância veterinária. A definição de retrovírus, nesta obra, está presente e correta, tendo inclusive (como visto anteriormente) seu ciclo descrito. Da mesma maneira que os outros dois livros, esse apenas descreve, de forma simples, as 
doenças virais, dando ênfase somente à AIDS. Ele também não destaca a importância que alguns vírus apresentam em relação à saúde pública da região Nordeste, seguindo a mesma problemática de que são utilizados livros de autores que não são dessa localidade. Nesta obra, há ainda textos sobre a ligação dos vírus com o câncer e sobre alguns vírus exóticos como o Ebola. É muito importante criar essa consciência, nos estudantes, de que alguns vírus estão ligados ao câncer, sendo necessário o diagnóstico e o tratamento precoce dessas viroses evitando o aparecimento de neoplasias, melhorando a qualidade de vida da população.

A obra 4 foi bastante completa em relação à estrutura viral, descrevendo todas as estruturas que os vírus podem possuir, com várias figuras ilustrando-as. Faltou apenas citar a existência do vírion, que é a forma intracelular dos vírus. É comentada também a importância das proteínas virais na interação com as células hospedeiras, destacando sua especificidade.

Os ciclos de replicação são bem representados por essa obra, tanto no texto quanto nas figuras, descrevendo os dois ciclos (lítico e lisogênico). É utilizado o bacteriófago como modelo, que também é corretamente definido como "vírus que infectam bactérias". No texto há uma menção ao fago T que infecta a bactéria E. coli, mostrando que é apenas um tipo de bacteriófago que faz isso e não todos, como a obra 1 escreveu. Também é descrito os ciclos de replicação de vírus, envelopados ou não, que infectam células animais.

Um ponto abordado por essa obra que não foi tratado pelos outros três autores já discutidos aqui, é a explanação acerca dos vírus vegetais dentro do capítulo. Neste tema, a obra dá ênfase à descrição do vírus do mosaico do tabaco (TMV) com esquemas e fotos do vírus, e fotos com sintomas da doença na planta. São destacados também os mecanismos de transmissão dos vírus vegetais por meio de vetores ou por meio da difusão mecânica, e propagação pelo pólen, sementes e reprodução vegetativa. Entretanto o autor não comenta, de forma explícita, a importância de se estudar os vírus de plantas de interesse econômico. Segundo Raven et al. (2001), há uma redução considerável na produtividade de muitos tipos de cultura devido a esses agentes infecciosos. Essas informações podem aumentar o interesse dos alunos pelo tema. Também não foi constatada nenhuma menção em relação aos vírus de importância veterinária, assim como nas outras obras.

Os processos de transcrição e tradução que ocorrem nos vírus também são explicados por esta obra. Os vírus de DNA utilizando a via DNA $>$ RNA Proteínas, os vírus de RNA utilizando RNA $>$ RNA $>$ Proteínas, e os retrovírus $\mathrm{RNA}>\mathrm{DNA}>\mathrm{RNA}>$ Proteínas. Estes últimos são definidos corretamente e bem exemplificados pelo autor, havendo até um texto extra sobre os mesmos. É importante que se dê essa ênfase aos retrovírus porque são vírus que causam doenças graves nos seres humanos como a leucemia (causado pelo HTLV) e a AIDS (causado pelo HIV).

As doenças virais são bem abordados pela obra demonstrando o tipo de vírus, a doença que causa, o modo de transmissão, características da infecção e 
profilaxia. O autor dá ênfase maior à AIDS e à dengue. Há ainda um texto sobre a vacina anti-HIV e tratamento de pessoas infectadas com o vírus da AIDS e outro sobre os vírus exóticos, assim como ocorre com as obras 2 e 3 . O texto sobre esses vírus, também é tema para discussão, o que é bom para os estudantes aumentarem seu conhecimento crítico à respeito dessas doenças. Apesar da abordagem ampla sobre as doenças virais, a obra não destaca as doenças que ocorrem mais frequentemente na região Nordeste, da mesma maneira que as obras 1, 2 e 3.

A obra 5 definiu bem as estruturas virais como o capsídeo, o material genético e o envelope; entretanto não comentou à respeito das glicoproteínas presentes no envelope lipídico, nem indicou essas estruturas nas ilustrações, o que dificulta a percepção dessas estruturas pelos alunos. É importante ressaltar a relação que a obra faz das estruturas virais com a sua especificidade em relação às células hospedeiras.

A replicação viral é abordada pela obra de forma bastante minuciosa, descrevendo o ciclo do bacteriófago $\mathrm{T}_{4}$, do vírus da gripe (vírus RNA) e de um retrovírus. Os três ciclos são bem descritos e acompanhados de ilustrações visando uma melhor aprendizagem dos estudantes. Um ponto negativo é que obra não comenta sobre o ciclo lítico e lisogênico.

Com relação aos fagos, a obra simplesmente fornece um exemplo do ciclo de replicação do bacteriófago $\mathrm{T}_{4}$, não definindo esse tipo de vírus, diferentemente das outras obras. Além disso, não há nessa obra, menção aos vírus vegetais e nem aos de importância veterinária. A obra apenas cita a ocorrência de doenças em plantas e animais na introdução do capítulo.

Os retrovírus são bem definidos no ponto do livro em que se fala da replicação desses vírus. A presença da enzima transcriptase reversa para produzir moléculas de DNA a partir de RNA, também é bem explicada. É importante a relação que a obra faz de alguns retrovírus com o câncer, ou seja, da presença de oncogenes nesses vírus.

As doenças virais são abordadas nessa obra por meio de um quadro onde relaciona a doença, o modo de transmissão, modo de infecção e as medidas de controle, assim como as outras obras (exceto a 1). Diferentemente das outras obras, essa não dá ênfase à AIDS que é uma doença importante, bastante disseminada no planeta. Além disso, não cita a dengue que é uma doença que ocorre bastante na região Nordeste e que deveria ser abordada de forma mais aprofundada.

A obra 6 comenta a estrutura viral de maneira bastante simples, não mostrando as possíveis estruturas que os vírus podem possuir como o envelope lipídico, glicoproteínas e a cauda dos bacteriófagos, que apenas são citadas na explicação de uma ilustração. É preciso que se descreva isso no texto também para que os alunos percebam que essa informação é importante, e não está ali meramente como um exemplo. Quanto às dimensões virais, a obra acerta demonstrando que eles oscilam entre 17 a $300 \mathrm{~nm}$.

O ciclo de replicação, nessa obra, é descrito também de forma simples. A obra não diferencia os ciclos em lítico e lisogênico, nem dá exemplos de ciclos de replicação de vírus de RNA, apenas utiliza um bacteriófago como modelo, 
mostrando seu ciclo lítico. Quanto aos fagos, o livro só aborda em duas figuras, uma com um esquema e outra com uma foto, e alguns fagos aderidos à superfície de uma bactéria. Isso ocorre, provavelmente, por ser um livro volume único, explicando a simplicidade e compactação das informações.

Não há nenhuma menção aos vírus vegetais e nem aos de importância veterinária. As doenças virais também são pouco exploradas nessa obra, a obra apenas cita algumas doenças que são causadas por vírus. Descrever essas doenças é importante para os estudantes entenderem melhor seus mecanismos de ação, e como proceder em um surto ou contágio com elas, e o autor não se preocupou com isso. Esclarecer que essas doenças ocorrem na região em que eles vivem também é importante para despertar o interesse deles pelo conteúdo. Os retrovírus são abordados nesse livro corretamente, inclusive o autor também explica outros vírus especiais, como os arbovírus que são vírus transmitidos por artrópodes, como o vírus Dengue.

\section{CONSIDERAÇÕES FINAIS}

A partir da análise da abordagem da Virologia nos livros didáticos de Biologia utilizados nessa pesquisa, conclui-se que existem erros conceituais que interferem no processo de aprendizagem, em que os alunos adquirem um conhecimento equivocado, embora algumas obras não tenham apresentado erros graves no que se refere aos conceitos mais básicos relativamente à temática aqui referida.

Foi possível detectar, na maioria dos livros, a ausência da relação entre o estudo dos vírus com outros assuntos abordados anteriormente, uma vez que apenas duas obras fizeram essa conexão. É extremamente relevante para o aluno perceber que os assuntos são interligados, e isso facilita bastante o processo de ensino-aprendizagem em Ciências e Biologia.

As obras não explicitam a importância de se estudar os vírus nem associam o conteúdo à realidade dos alunos, diminuindo a motivação e consequentemente o aprendizado. Conclui-se também que esses livros didáticos se baseiam em uma aprendizagem mecânica, que simplesmente se prende a fornecer a nova informação sem se apoiar em qualquer conhecimento prévio, não favorecendo assim a aprendizagem significativa.

Os livros didáticos analisados aqui não estão completamente aptos para serem usados como material de apoio no que diz respeito à Virologia. Uma atualização destes ou a confecção de outros recursos didáticos e sua utilização na sala de aula pode ser uma maneira de contornar essa deficiência.

Ainda existe uma carência grande de trabalhos que tenham como objetivo analisar a abordagem dos diversos assuntos das Ciências Biológicas nos livros didáticos. Assim, futuras pesquisas sobre a avaliação da qualidade desses livros didáticos são necessárias para apontar eventuais deficiências acerca de outros assuntos das Ciências Biológicas, ou explorar ainda mais a Virologia, mostrando como ela poderia ser melhor abordada por esses livros. 


\section{AGRADECIMENTOS}

Agradecemos ao CNPq pelo apoio financeiro e bolsa de estudo do primeiro autor.

\section{REFERÊNCIAS BIBLIOGRÁFICAS}

ABUD, K. M. O Livro didático e a popularização do saber. In: SILVA, M. A. (Org.). Repensando a história. 3.ed. São Paulo: Marco Zero, 1994. p. 81-87.

BRASIL. Ministério da Educação. Parâmetros Curriculares Nacionais do Ensino Médio. Brasília, 1999. Secretaria de Educaşão Fundamental - avaliação de livros didáticos de $1^{a}$ a $8^{a}$ série. 2002. Disponível em: <http://portal.mec.gov.br/seb>. Acesso em: 10 abril 2006.

Secretaria de Educaşão Básica - programa nacional do livro didático para o ensino médio. 2006. Disponível em: <http://portal.mec.gov.br/seb>. Acesso em: 27 julho 2006 .

. Catálogo do Programa Nacional do Livro para o Ensino Médio. Secretaria de Educação Básica. Brasília, 2006b.

CARLINI-COTRIM, B.; ROSEMBERG, F. Os livros didáticos e o ensino para a saúde: o caso das drogas psicotrópicas. Revista de Saúde Pública, São Paulo, v. 25, n. 4, p. 299-305, 1991.

CHEVAllarD, Y. A Transposição Didática. Porto Alegre: Artmed, 1999.

COLLETTO, A. D. A importância do aperfeiçoamento profissional, 2005. Disponível em:

$<$ http://maca.cptec.inpe.br/noticias.php?ntc=48>. Acesso em: 31 agosto 2006.

JÁCOME, M. Automedicação - uma prática de dois gumes e consequências preocupantes. Agenda Saúde, 2001. Disponível em: <http://www.agendasaude.com.br/materias/index.asp?cod=238>. Acesso em: 25 agosto 2006.

LIBÂNIO, J. C. Didática. São Paulo: Cortez, 1994.

MARTINS, I.; GOUVÊA, G. Analisando aspectos da leitura de imagens em livros didáticos de ciências por estudantes do ensino fundamental no Brasil. Enseñanz̧a de las Ciências. Número extra, VII congresso, p. 1-3, 2005.

NÚÑEZ, I. B.; RAMALHO, B. L.; SILVA, I. K. P.; CAMPOS, A. P. N. A seleção dos livros didáticos: um saber necessário ao professor. O caso do ensino de ciências. Revista Iberoamericana de Educación. Madrid, 2003.

RÁCZ, M. L.; MENCK, C. F. M. Propriedades gerais dos vírus. In: TRABULSI, L. R.; ALTERTHUM, F. Microbiologia. 4.ed. São Paulo: Atheneu, 2004, p. 509-514.

RAMALHO, B. L.; NÚÑEZ, I. B.; GAUTHIER, C. Quando o desafio é mobilizar o pensamento pedagógico do professor: uma experiência centrada na formação continuada. Associação Nacional de Pós-graduação e Pesquisa em Educação. 2000. Disponível em: <http://www.anped.org.br>. Acesso em: 10 abril 2006.

RAVEN, P. H.; EVERT, R. F.; EICHHORN, S. E. Biologia Vegetal. 6.ed. Rio de Janeiro: Guanabara Koogan, 2001.

GARCÍA, M. M. T.; IZQUIERDO, A. M.; FIEDLER-FERRARA, N.; MATTOS, C. R. Un estudio sobre la evaluación de libros didácticos. I Encuentro Ibero-americano sobre Investigación en Educación en Ciencias. Burgos, 2002, p. 16-21.

VASCONCELOS, S. D.; SOUTO, E. O livro didático de ciências no ensino fundamental proposta de critérios para análise do conteúdo zoológico. Ciência e Educaşão. São Paulo, v. 9, n. 1, p. 93-104, 2003. 